\title{
Plate tectonics and biogeographical patterns of the Pseudophoxinus (Pisces: Cypriniformes) species complex of central Anatolia, Turkey
}

\author{
Tomas Hrbek, ${ }^{\mathrm{a}, \mathrm{e}, *}$ Kai N. Stölting, ${ }^{\mathrm{a}}$ Fevzi Bardakci, ${ }^{\mathrm{b}}$ Fahrettin Küçük, \\ Rudolf H. Wildekamp, ${ }^{\mathrm{d}}$ and Axel Meyer ${ }^{\mathrm{a}}$ \\ ${ }^{a}$ Department of Biology, University of Konstanz, 78464 Konstanz, Germany \\ ${ }^{\mathrm{b}}$ Department of Biology, Faculty of Science and Literature, Cumhuriyet University, 58140 Sivas, Turkey

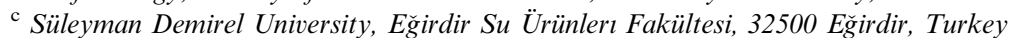 \\ ${ }^{\mathrm{d}}$ Royal Museum of Central Africa, Vertebrate Section, 3080 Tervuren, Belgium

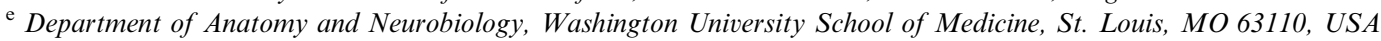

Received 14 August 2003; revised 12 December 2003

Available online 3 March 2004

\begin{abstract}
We investigated the phylogenetic relationships of Pseudophoxinus (Cyprinidae: Leuciscinae) species from central Anatolia, Turkey to test the hypothesis of geographic speciation driven by early Pliocene orogenic events. We analyzed 1141 aligned base pairs of the complete cytochrome $b$ mitochondrial gene. Phylogenetic relationships reconstructed by maximum likelihood, Bayesian likelihood, and maximum parsimony methods are identical, and generally well supported. Species and clades are restricted to geologically well-defined units, and are deeply divergent from each other. The basal diversification of central Anatolian Pseudophoxinus is estimated to have occurred approximately 15 million years ago. Our results are in agreement with a previous study of the Anatolian fish genus Aphanius that also shows a diversification pattern driven by the Pliocene orogenic events. The distribution of clades of Aphanius and Pseudophoxinus overlap, and areas of distribution comprise the same geological units. The geological history of Anatolia is likely to have had a major impact on the diversification history of many taxa occupying central Anatolia; many of these taxa are likely to be still unrecognized as distinct.
\end{abstract}

Keywords: Pseudophoxinus sp. complex; Anatolia; Turkey; Biogeography; Tethys; Speciation; Molecular phylogeny

\section{Introduction}

Allopatric speciation is the primary mode of speciation in nature (Futuyma, 1998; Futuyma and Mayer, 1980; Mayr, 1942), and geographic speciation is viewed as the most common mode of allopatric speciation (Futuyma and Mayer, 1980). Under the geographic speciation model a population is divided into two or more sub-populations as a result of a formation of a geographic barrier, preventing among sub-population gene flow, and facilitating divergence sufficient to form distinct species. Geologically active regions containing

\footnotetext{
${ }^{*}$ Corresponding author. Fax: 1-314-362-3446.

E-mail address: hrbek@pcg.wustl.edu (T. Hrbek).
}

many geographically isolated areas should, therefore, be ideal candidates for testing the geographic speciation hypothesis. The closure of the Tethys Sea provides a particularly rich series of geological events (Sengör et al., 1988) that could have led to geographic speciation. In this study we focus on Anatolia, the Asiatic part of Turkey, which has a rich and well-studied geologic history (Sengör and Yilmaz, 1981).

Hrbek et al. (2002) investigated the role of central Anatolian plate tectonic events on the diversification and phylogenetic relationships of cyprinodontiform fishes of the genus Aphanius. The study resulted in the discovery of seven highly supported and phylogenetically deeply divergent clades that showed little or no morphological differentiation among each other. 
The clades were estimated to have diverged 11.5-14.1 million years ago (Hrbek et al., 2002). Representatives of those clades that have been investigated (Villwock, 1964) show complete or partial postmating reproductive isolation, and by many criteria may represent distinct species. On a smaller geographic scale Weisrock et al. (2001) investigated the diversification of Mertensiella luschani complex of salamanders in the southwestern section of the Menderez-Taurus block of Turkey, finding up to 7 million year divergences among populations within this region. Reproductive isolation among these populations was also inferred (Weisrock et al., 2001). In contrast to these studies, a recent study of the Rana macrocnemis species complex of central Anatolia by Veith et al. (2003) showed that populations inhabiting various Anatolian geological plates are of Pleistocene origin, having dispersed from a Transcaucasian refugium. The southwestern section of the Menderez-Taurus block of Turkey, the same geographic region studied by Weisrock et al. (2001) and Hrbek et al. (2002), formed another refugium in $R$. macrocnemis. However, this refugium did not act as a source of colonists. Thus, we have conflicting patterns of faunal diversification in central Anatolia driven by Pliocene orogenic events in fish and salamanders, or by Pleistocene glacial events in frogs.

In this study we investigate the phylogenetic relationships of species of the fish genus Pseudophoxinus of Turkey with the specific goal of testing the hypothesis that the geological events shaping Anatolia have driven the patterns of diversification in multiple organismal groups, and in particular in fish groups. If this hypothesis is true, we should see the same or non-significantly different branching order of phylogenetic relationships in Pseudophoxinus as in Aphanius, and the timing of the diversification events should be congruent between these two genera.

The genus Pseudophoxinus is found in a wide range of habitats and is often co-distributed with Aphanius in central Anatolia. Although recently revised by Bogutskaya (1992), some taxonomic problems still exist. Prior to undertaking the present molecular study, we classified our specimens according to the meristic characters presented in Bogutskaya (1992). We were unable to assign many of our specimens to the species defined by Bogutskaya (1992) without the addition of collecting locality data. This finding pertained to the species $P$. fahirae, $P$. meandri, $P$. meandricus, and $P$. anatolicus, which constitute the widely distributed main central Anatolian radiation. For the purpose of this publication, the taxonomic assignments are tentative, and these species are often discussed in terms of geographically restricted clades. The other species $P$. antalyae, $P$. handlirschi, $P$. battalgili, $P$. crassus, $P$. kervillei, and $P$. egridiri could be classified unambiguously. We also included a newly discovered species from the thermal spring-head of the Tohma Çayı, an upper tributary of the Euphrates River.

\section{Materials and methods}

\subsection{Selection of outgroup and ingroup taxa}

To investigate phylogenetic relationships among the central Anatolian Pseudophoxinus species complex, Pseudophoxinus were collected from 22 localities. Pseudophoxinus could be identified as: $P$. anatolicus (7 populations), $P$. cf. anatolicus (1 population), P. meandri (4 populations), P. fahirae (2 populations), $P$. antalyae (2 populations), $P$. handlirschi (1 population), P. battalgili (1 population), P. crassus (2 populations), $P$. kervillei (1 population), and $P$. sp. nov. (1 population). We chose members of the genera Leuciscus and Phoxinellus from the Adriatic and Danubian drainages, and the genus Chondrostoma as outgroups. The chosen outgroups represent the closest outgroups from an analysis of Eurasian leuciscine fishes (Hrbek et al. unpublished data; Zardoya and Doadrio, 1999). Pseudophoxinus egerdiri from Lake Eğridir in Turkey is not a member of the clade comprising the other Anatolian species of Pseudophoxinus; rather it appears to be the sister taxon to Phoxinus phoxinus (Hrbek et al. unpublished data), a widely spread Eurasian species. Therefore it was not included in the here presented sets of analyses. Table 1 lists species and populations used in the study, as well as their GenBank accession numbers.

\subsection{Laboratory protocols}

Total genomic DNA was extracted from muscle tissue of the right caudal peduncle of specimens preserved in $95 \%$ ethanol. Muscle tissue was dissolved and digested with a proteinase K/SDS solution, followed by phenol and chloroform extraction, and the addition of $5 \mathrm{M} \mathrm{NaCl}$ followed by $70 \%$ ethanol precipitation of DNA product.

Polymerase chain reaction (PCR) amplification was performed on total genomic DNA. Negative controls were performed for all reactions. The temperature profile for the 30-cycle amplification reaction consisted of denaturation at $94{ }^{\circ} \mathrm{C}$ for $35 \mathrm{~s}$, annealing at $50^{\circ} \mathrm{C}$ for $35 \mathrm{~s}$, and extension at $72^{\circ} \mathrm{C}$ for $90 \mathrm{~s}$ per cycle. The resulting products were evaluated on a $1.2 \%$ agarose gel, and then purified with Qiagen spin-columns. Amplified mtDNA segments were sequenced from both the $5^{\prime}$ and $3^{\prime}$ ends. Sequencing reactions followed the standard Perkin-Elmer Big Dye sequencing protocol for doublestranded cycle sequencing reactions. Sequences were determined on a Perkin-Elmer ABI 3100 automatic DNA sequencer. Amplification and sequencing primers were L14725 (5'-GAYTTGAARAACCAYCGTTG-3') located in the tRNA ${ }^{\text {Glu }}$ and H15982 (5'-CCTAGCTTTGGGAGYT AGG-3') located in the $\mathrm{RNA}^{\text {Pro; }}$; a primer designation corresponds to its $3^{\prime}$ position on the heavy $(\mathrm{H})$ or light 
Table 1

Species and localities included in this study

\begin{tabular}{|c|c|c|c|}
\hline Species & Clade & Population & GenBank Accession No. \\
\hline \multicolumn{4}{|l|}{ Spain } \\
\hline Chondrostoma arcasii & & Duero Drainage & AF045979 \\
\hline Chondrostoma lemingii & & Guadalquivir Drainage & AF045989 \\
\hline Chondrostoma polylepis & & Tajo Drainage & AF045982 \\
\hline Chondrostoma toxostoma & & Ebro Drainage & AF045985 \\
\hline \multicolumn{4}{|l|}{ Portugal } \\
\hline Chondrostoma macrolepidotus & & Mondego Drainage & AF045980 \\
\hline \multicolumn{4}{|l|}{ Greece } \\
\hline Chondrostoma prespense & & Prespa Drainage & AF090747 \\
\hline Chondrostoma vardarense & & Aoos Drainage & AF090749 \\
\hline Pseudophoxinus beoticus & & Kifissos Drainage & AF090770 \\
\hline Leuciscus pleurobipunctatus alfiensis & & Alphios Drainage & AF090765 \\
\hline Leuciscus pleurobipunctatus pleurobipunctatus & & Arachthos Drainage & AF090764 \\
\hline \multicolumn{4}{|l|}{ Italy } \\
\hline Leuciscus souffia multicellus & & Sieve & AY494739 \\
\hline \multicolumn{4}{|l|}{ Austria } \\
\hline Leuciscus souffia agassi & & Enns River & AY494740 \\
\hline \multicolumn{4}{|l|}{ Croatia } \\
\hline Chondrostoma phoxinus & & Vrba River & AY494741 \\
\hline Phoxinellus dalmaticus & & Vrba River & AY494742 \\
\hline Leuciscus turskyi & & Vrba River & AY494743 \\
\hline Leuciscus polylepis & & Jezerane & AY494744 \\
\hline \multicolumn{4}{|l|}{ Bosnia and Herzegovina } \\
\hline Phoxinellus metohiensis & & Nevesinje & AY494745 \\
\hline Phoxinellus alepidotus & & Glamsco near Tomislavgrad & AY494746 \\
\hline \multicolumn{4}{|l|}{ Turkey } \\
\hline Pseudophoxinus cf. anatolicus & (I) & Soysali Spring, Develi Depression & AY494747 \\
\hline Pseudophoxinus anatolicus (1) & (III) & Lake Çavuşçu & AY494748 \\
\hline Pseudophoxinus anatolicus (2) & (III) & Lake Beyşehir by Yeşildağ & AY494749 \\
\hline Pseudophoxinus anatolicus (3) & (III) & Kızılca & AY494750 \\
\hline Pseudophoxinus anatolicus (4) & (III) & Akkaya Baraji & AY494751 \\
\hline Pseudophoxinus anatolicus (5) & (III) & Akgöl by Ereğli* & AY494752 \\
\hline Pseudophoxinus anatolicus (6) & (III) & İnsuyu Koyü & AY494753 \\
\hline Pseudophoxinus anatolicus (7) & (III) & Goyöz & AY494754 \\
\hline Pseudophoxinus meandri (1) & (IV) & Lake Karataş & AY494755 \\
\hline Pseudophoxinus meandri (2) & (IV) & Düger DSI Pump station & AY494756 \\
\hline Pseudophoxinus meandri (3) & (IV) & Lake Salda & AY494757 \\
\hline Pseudophoxinus meandri (4) & (IV) & Kırkpınar by Yeşilova & AY494758 \\
\hline Pseudophoxinus fahirae (1) & (VI) & Lake Avlan & AY494759 \\
\hline Pseudophoxinus fahirae (2) & (VI) & Kirkpınar north of Sögüt* & AY494760 \\
\hline Pseudophoxinus antalyae (1) & - & Kırkgöz $z^{*}$ & AY494761 \\
\hline Pseudophoxinus antalyae (2) & - & Köprüçayı by Sağırın & AY494762 \\
\hline Pseudophoxinus crassus & - & İnsuyu Koyü* & AY494763 \\
\hline Pseudophoxinus crassus & - & Güneşli south of Eşmekaya & AY494764 \\
\hline Pseudophoxinus battalgili & - & Eflatun Pinari* & AY494765 \\
\hline Pseudophoxinus handlirschi & - & Köprü Irmak by Aksu & AY494766 \\
\hline Pseudophoxinus spec. nov. & - & Gögdeli Hot Springs, Tohma Çayı & AY494767 \\
\hline Pseudophoxinus kervillei & - & Former Lake Amik south of Kırıkhan & AY494768 \\
\hline
\end{tabular}

Ingroup species collected from type localities are indicated with an asterisk $\left({ }^{*}\right)$ and GenBank accession numbers indicated.

(L) strands of the human mitochondrion (Anderson et al., 1981). The mtDNA region analyzed comprised the complete cytochrome $b$ gene. At least two individuals per population were completely sequenced to assure that individuals were representative of their populations, however, only one randomly selected individual was used in the analyses.

\subsection{Data analysis}

Homologous regions were aligned manually against previously published cytochrome $b$ sequences of leuciscine fishes (Zardoya and Doadrio, 1999) and confirmed by translating DNA data into amino acid sequences in BioEdit (Hall, 1999). Total sequence length was 1141 
characters. All sequences were tested for an anti-G bias characteristic of mitochondrial DNA genes, to confirm that we have collected genuine mitochondrial DNA data (Zhang and Hewitt, 1996).

Maximum parsimony-based phylogenetic relationships were estimated using the program PAUP* (Swofford, 2001) with 100 heuristic searches using random additions of sequences, and implementing the tree bisection and reconnection (TBR) algorithm. Equal weight was given to all characters. Bootstrap resampling (Felsenstein, 1985) was applied to assess support for individual nodes using 2000 bootstrap replicates with 10 random additions and TBR branch swapping.

Maximum likelihood-based phylogenetic relationships were estimated using the program PAUP* (Swofford, 2001) and implementing a full heuristic search of the tree space. ModelTest vers. 3.04 (Posada and Crandall, 1998) indicated that the best-fit model of nucleotide substitution was the GTR model of evolution (Rodriguez et al., 1990) with some sites assumed to be invariable and with variable sites following a discrete gamma distribution $(\mathrm{GTR}+\mathrm{I}+\Gamma)$. All parameters were estimated by the maximum likelihood method.

Bayesian likelihood-based phylogenetic relationships were estimated using the program MrBayes 2.01 (Huelsenbeck and Ronquist, 2001). The data were partitioned into three classes (codon positions 1, 2, and 3 of cyt $b$ ). A GTR $+\mathrm{I}+\Gamma$ model of evolution was used. We ran 5,000,000 generations, sampling trees and branchlength every 100 generations. We discarded the lower $10 \%$ of the trees in the computation of a $50 \%$ majority rule consensus tree. Following Huelsenbeck and Ronquist (2001) the percentage of times a clade occurs among the sampled trees was interpreted as the probability of that clade existing. These probabilities are true probabilities under the assumed model of substitution (Rannala and Yang, 1996); thus we considered clades to be significantly supported when Bayesian posterior probabilities were $\geqslant 95 \%$.

To generate a distance matrix used in the molecular clock calibration compatible with the results of Zardoya and Doadrio (1999), we used the HKY85 model of evolution (Hasegawa et al., 1985) with an empirically based transition/transversion ratio. The distance matrix was generated under the assumption of a molecular clock as in Zardoya and Doadrio (1999). A molecular mutation rate of $7.9 \times 10^{-8}$ per site per year (Zardoya and Doadrio, 1999) was used in the calculation of divergence times.

Congruence among Pseudophoxinus and Aphanius topologies was tested by enforcing a topological constraint compatible with Aphanius topology on Pseudophoxinus in PAUP* (Swofford, 2001), finding a most likely tree topology satisfying that constraint, and then using the Shimodaira-Hasegawa test (Shimodaira and Hasegawa, 1999) to test for significant differences be- tween the most likely constrained and unconstrained Pseudophoxinus topologies.

All sequence data have been deposited in GenBank (Table 1). The aligned data are available directly from the first author, and have been deposited at www.treebase.org.

\section{Results}

The cytochrome $b$ sequences were aligned unambiguously and without any gaps. DNA sequences were translated into amino acid sequence in BioEdit (Hall, 1999) and producing full-length reads with no internal stop codons. The base pair composition (average $\mathrm{A}=0.26308, \mathrm{C}=0.28184, \mathrm{G}=0.16682, \mathrm{~T}=0.28825$ ) shows the characteristic anti-G bias of mitochondrial genes but not of nuclear genes (Zhang and Hewitt, 1996). The data contain large number of informative characters, both with the outgroup, and between the outgroup and the ingroup. The number of parsimony informative characters (336) was more than eight times the number of taxa (40) sampled. The ingroup data, the Turkish Pseudophoxinus, contain 226 parsimony informative characters. Uncorrected sequence divergence between individuals within a population ranged from 0.00 to $0.06 \%$, and 5.06 to $11.73 \%$ among major clades and species of Turkish Pseudophoxinus.

\subsection{Phylogenetic relationships}

We conducted three separate sets of analyses. The data were analyzed using maximum parsimony, maximum likelihood, and Bayesian likelihood. The resulting phylogenies are identical with respect to the ingroup topology. Pseudophoxinus clades correspond to geographically well-defined areas, and overlap with killifishes of the Aphanius anatoliae species complex (Hrbek et al., 2002); for ease of comparison, we use the same area/clade designation in Pseudophoxinus as were used in the study of Aphanius (Hrbek et al., 2002). The four major overlapping Pseudophoxinus clades inhabit the Sultan swamps of the Develi depression (Figs. 1 and 2, Clade I; P. cf. anatolicus), the Tuzgölü basin (Figs. 1 and 2, Clade III; P. anatolicus), the Lakes District (Figs. 1 and 2, Clade IV; P. meandri ?), and the Southwest Bey Dağları region (Figs. 1 and 2, Clade VI; P. fahirae ?). Pseudophoxinus antalyae inhabits the Alanya block (Fig. 1) and forms a sister group to clades IV and VI of Pseudophoxinus (Fig. 2). Pseudophoxinus handlirschi and $P$. battalgili were originally from Lakes Eğirdir and Beyşehir, respectively, but now are extinct in the lakes and restricted to surrounding drainages due to the introduction of the predatory zander Sander lucioperca. Pseudophoxinus crassus appears to be restricted to the Insuyu Creek, and the immediate southeastern vicinity 


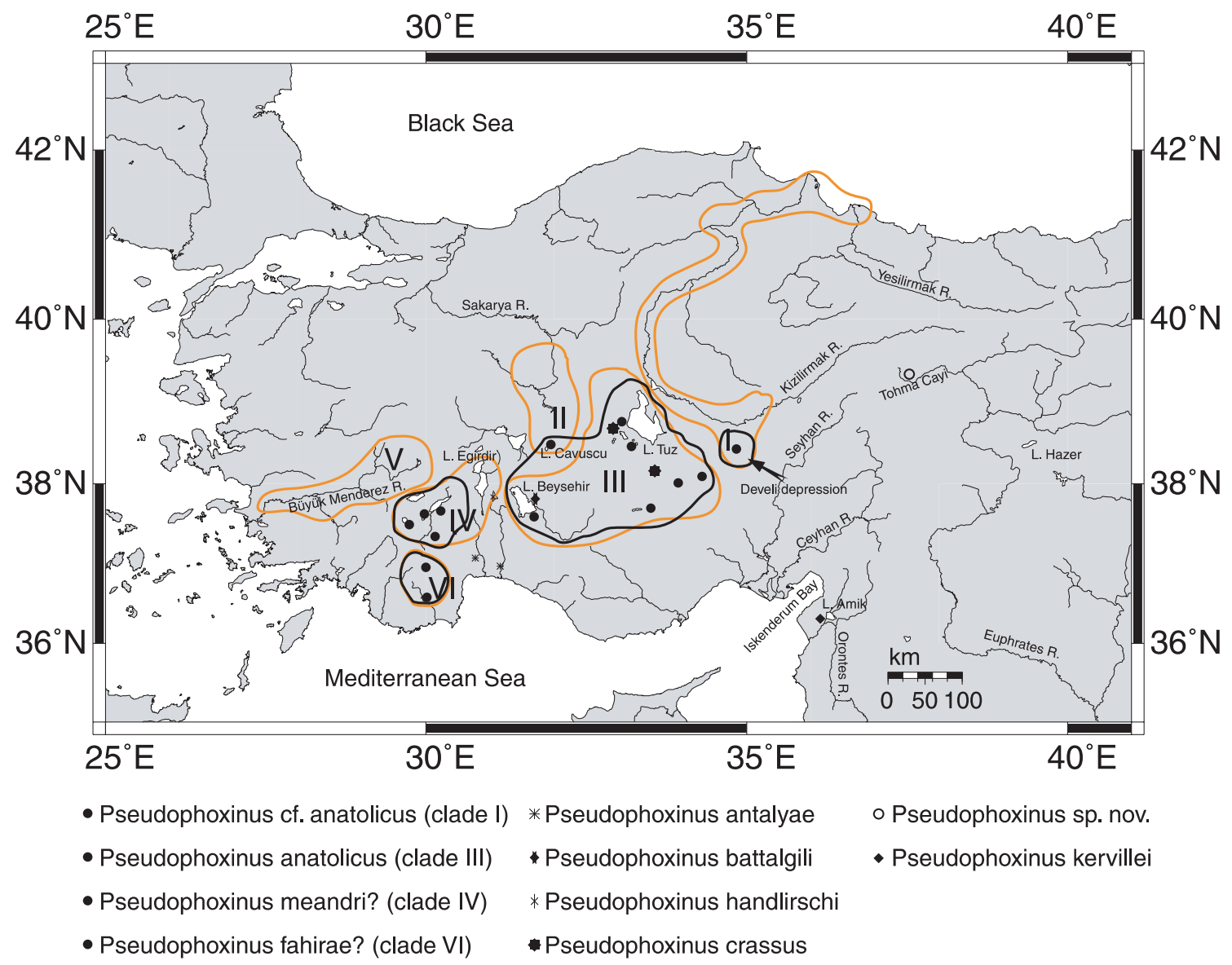

Fig. 1. Distribution area of the cyprinids of the genus Pseudophoxinus. Localities included in this study are marked by species specific symbols. Roman numerals correspond to: I, Develi Depression clade; III, Tuzgölü plain clade; IV, Lakes District clade; and VI, Southwestern Bey Dağları clade. The clade numerations are identical to those of the genus Aphanius (Hrbek et al., 2002). Aphanius clades are outlined in light gray, and also show the Sakarya drainage clade (clade II) and the Büyük-Menderez clade (clade V). (For interpretation of the references to color in this figure legend, the reader is referred to the web version of this paper.)

of Lake Tuz, and overlaps in distribution with clade III Pseudophoxinus. Sister group to the central Anatolian clade are Pseudophoxinus kervillei from the Orontes River drainage and coastal drainages of the İskenderun Bay, and a newly discovered Pseudophoxinus species from the Gögdeli thermal springs at the source of the Tohma Çay, an upper Euphrates River tributary.

Haplotype sharing among clades is not observed, suggesting complete isolation of individual clades. The average pair-wise divergence of the phylogenetically deepest node is $12.1 \%$, suggesting a 15.9 -million-year-old divergence, while the deepest average pair-wise divergence within central Anatolian Pseudophoxinus is 11.5\%, suggesting a 15.1-million-year-old divergence. The divergence times were estimated based on a substitution rate of $0.76 \%$ pair-wise sequence divergence per million years estimated for leuciscine fishes by Zardoya and Doadrio (1999). The estimated timing of diversification of Anatolian Pseudophoxinus corresponds closely to that of Aphanius (14.1 million years, geological calibration independent of Pseudophoxinus; Hrbek and Meyer,
2003) occupying the same geographic areas. Similarly, the pattern of low levels of intra clade III divergence in Aphanius (Hrbek et al., 2002) is also observed in Pseudophoxinus ( $0.6 \%$ average pair-wise sequence divergence). The divergence of $P$. antalyae from its sister group (Pseudophoxinus clades IV + VI) is estimated at 6.2\% pair-wise sequence divergence which corresponds to approximately 8.2 million year divergence. The timing of this divergence is concordant with geological predictions of 5-10 million years derived from the collision of the Alanya massif with the southwestern section of the Taurus-Menderez block (Quennell, 1984; Waldron, 1984). This event effectively separated the Lakes District region (clade IV) from the Dağları mountains (clade VI) and the Alanya massif ( $P$. antalyae).

While the monophyly of the Anatolian Pseudophoxinus is not strongly supported (Fig. 3), it consistently appears in all phylogenetic analyses. The relationship among the three phylogenetically deepest clades of the ingroup is also not well supported, nor is the relationship among $P$. antalyae, and Pseudophoxinus clades IV 


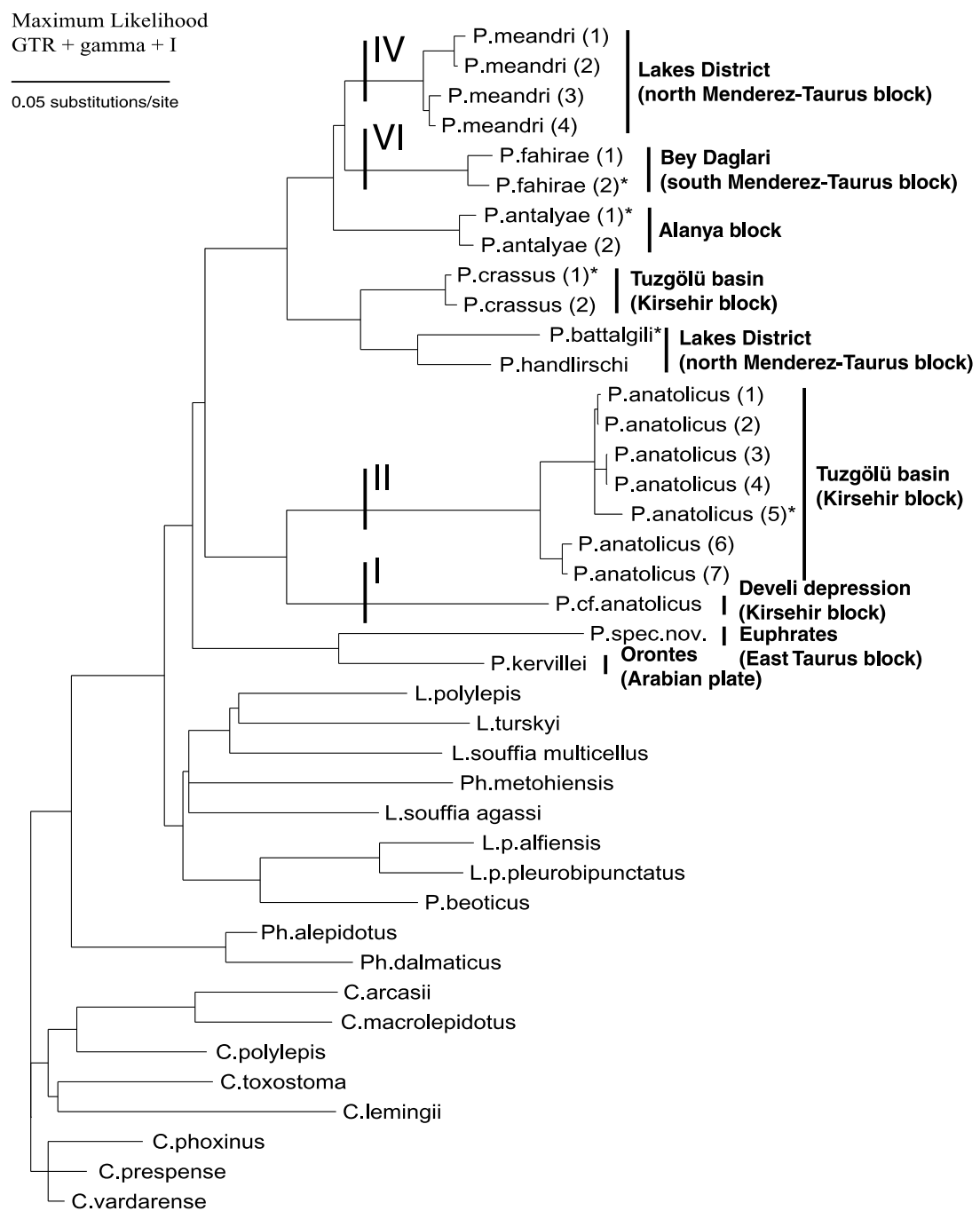

Fig. 2. Maximum likelihood estimate of the phylogenetic relationships of the genus Pseudophoxinus based on 50 random additions and TBR rearrangements of the best maximum likelihood topology. For the GTR $+\mathrm{I}+\Gamma$ model transitions probabilities were determined empirically, the shape parameter alpha equals 1.31053 and the proportion of invariable sites is $0.57037 ;-\ln =8168.09690$. Maximum parsimony estimate is equal to the maximum likelihood phylogeny for ingroup relationships; $\mathrm{TL}=1485, \mathrm{CI}=0.3734$. Numbers after specific names refer to geographic locations listed in Table 1 from which the specimens originate. Clade designations are indicated by labeled bars and correspond to clades in Fig. 1 . Asterisk $(*)$ after a species name indicates an individual collected from the type locality.

and VI. Most other ingroup relationships are well supported (Fig. 3).

\subsection{Geographic distribution}

Pseudophoxinus clade I occurs in the Develi Depression and forms a sister taxon to clade III occurring in the Tuzgölü basin. Nested within the Tuzgölü clade is a Pseudophoxinus population from the wetland areas on the southern edge of Lake Beyşehir. Lake Beyşehir is connected to the Konya plain in the center of the distribution of clade III by an irrigation canal. Based on historical records and maps, the construction of the $68 \mathrm{~km}$ long irrigation canal was started in 1914, and completed within two years. The canal itself is the channelized and regulated river Çarşamba which acted as a natural drainage of Lake Beyşehir, emptying into a large wetland in the Tuzgölü basin; the wetland was historically located south of the city Konya, and has been drained for agricultural purposes in the earlier part of this century. Close relationship of Lake Beyşehir and Tuzgölü basin populations parallels the pattern seen in the $A$. anatoliae populations from the same region (Fig. 1; Hrbek et al., 2002). Fishes of this clade also occur in the Lake Çavuşçu where previous to our collections no Pseudophoxinus have been recorded. No Pseudophoxinus have been collected in the upper Sakarya River basin either, the provenance of Aphanius clade II (Fig. 1; Hrbek et al., 2002). Since recently an irrigation canal from Lake Beyşehir has been constructed to Lake Çavuşçu, it is most probable that the Pseudophoxinus in Lake Çavuşçu are recent invaders 


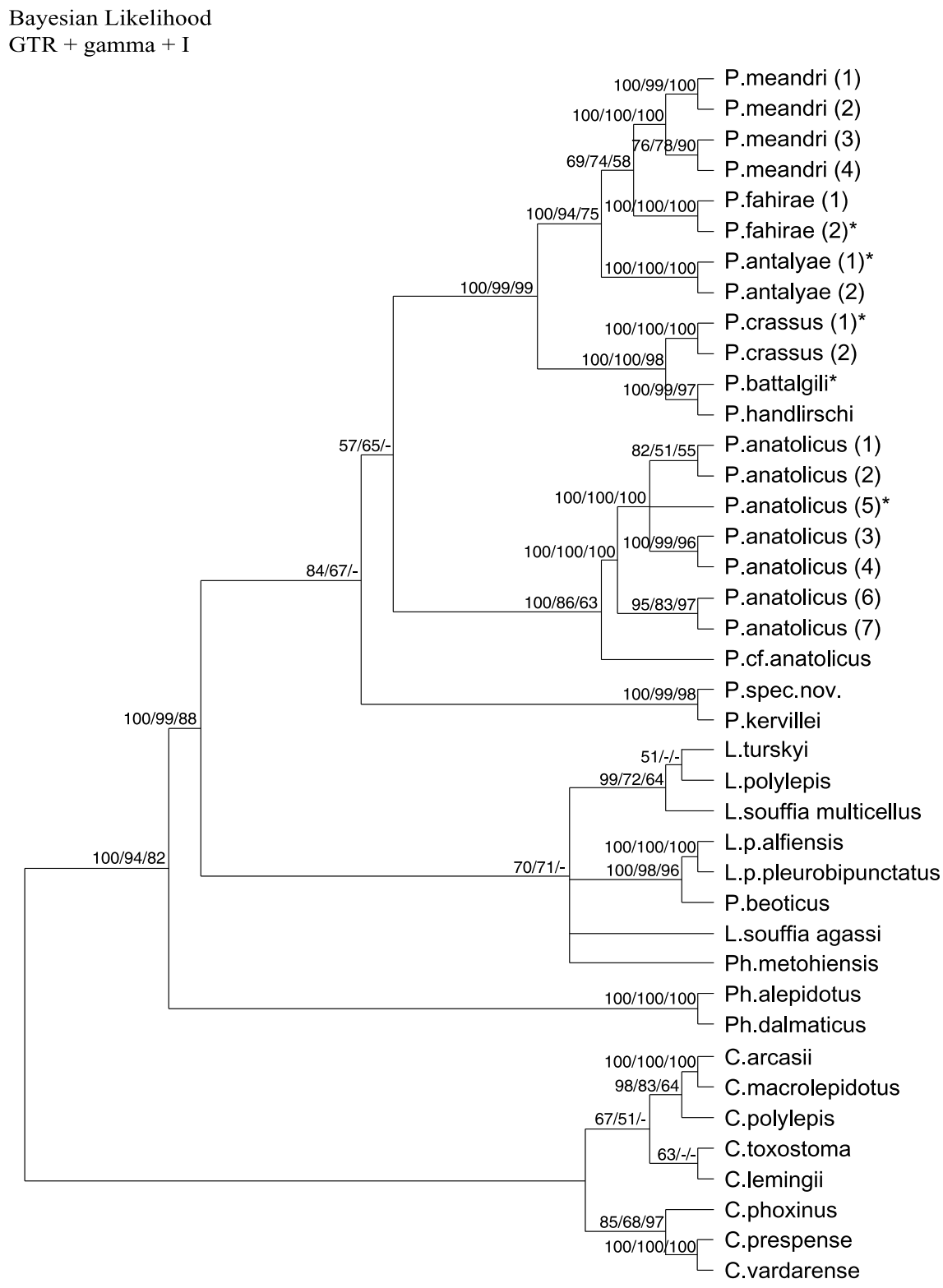

Fig. 3. A Bayesian likelihood hypothesis of phylogenetic relationships of genus Pseudophoxinus based on 5,000,000 replicates. Bayesian likelihoods are listed above nodes, followed by maximum likelihood bootstrap values and maximum parsimony bootstrap values. Maximum likelihood bootstrap values are based on 500 replicates and maximum parsimony bootstrap values are based on 2000 replicates.

from the southern Lake Beyşehir region where they live in wetlands and small creeks.

Clade VI of Pseudophoxinus occurs in the Bey Dağları region of the Menderez-Taurus block and forms a sister clade to clade IV distributed in the Lakes District of the Menderez-Taurus block. These two clades also overlap closely with Aphanius of the region (Fig. 1). Clades IV and VI form a sister clade to $P$. antalyae found on the Alanya massif, an area where the Aphanius anatoliae species complex does not occur. This Pseudophoxinus assemblage is a sister clade to $P$. crassus, $P$. handlirschi, and P. battalgili.

The two largest central Anatolian freshwater lakes were inhabited by endemic species of Pseudophoxinus.
Lake Eğirdir had $P$. handlirschi that is now restricted to one montane creek in the upper Akşu River drainage. Lake Beyşehir had P. battalgili that is now restricted to Eflatun Pinar1, a spring feeding into a wetland on the eastern shore of the lake, and Soguksu Köprüsü, a creek entering Lake Beyşehir at its southwestern corner. Introduced predators, in particular the zander $S$. lucioperca, are responsible for the extirpation of many native species of these large freshwater lakes including Pseudophoxinus.

Pseudophoxinus crassus appears unique in having a naturally overlapping distribution with members of clade III Pseudophoxinus. It appears to be restricted to the İnsuyu Creek, and the immediate southeastern 
vicinity of Lake Tuz. Interestingly, clade III Pseudophoxinus populations in this area are genetically differentiated from other clade III populations $(0.6 \%$ average pair-wise sequence divergence) that otherwise show minimal among population differentiation. The sister groups to all central Anatolian Pseudophoxinus and Aphanius populations inhabit the eastern mountains of Turkey, and in the case of Pseudophoxinus also the Orontes River drainage.

\section{Discussion}

\subsection{Evolution of central Anatolian Pseudophoxinus species}

The evolutionary history of Anatolian Pseudophoxinus species closely parallels the evolutionary history of the Aphanius anatoliae species complex (Hrbek et al., 2002). Not only are Pseudophoxinus clades geographically restricted, the clades of both groups show an overlapping pattern. For illustration purposes the same clade designations are used for both genera/species (Fig. 1; Hrbek et al., 2002). The congruence among the patterns of these two fish groups is not perfect, however. Pseudophoxinus antalyae is found in a region unoccupied by any member of the $A$. anatoliae species complex, while Pseudophoxinus species are not present in the Kızılırmak and Yeşilırmak River drainages where $A$. danfordii, a clade I member of the $A$. anatoliae species complex occurs; Pseudophoxinus also seems not to occur naturally in the Sakarya River drainage where $A$. villwocki, a clade II member of the $A$. anatoliae species complex occurs (Hrbek et al., 2002). Records in the Hamburg Museum of Zoology indicate that a Pseudophoxinus species are found in the Büyük-Menderez River drainage basin (clade V) where yet another member of the $A$. anatoliae species complex occurs (Hrbek et al., 2002). However, extensive collecting efforts over six seasons from 1996 to 2002 failed to turn up any specimens of Pseudophoxinus in the Büyük-Menderez River drainage basin.

Historically Lakes Beyşehir and Eğirdir were occupied by the endemic $P$. battalgili and $P$. handlirschi, respectively. In contrast to Pseudophoxinus, Aphanius from Lakes Beyşehir and Eğirdir belong to clades III and IV, respectively. Although these lakes do not contain endemic species of Aphanius, at least in the case of the Lake Eğirdir population, Aphanius is documented to have morphological adaptations for inhabiting and exploiting open-water habitats (Wildekamp et al., 1999). As a result of the introduction of fish predators, Pseudophoxinus has been extirpated and Aphanius largely extirpated from both lakes; Pseudophoxinus now occurs only in few surrounding streams while Aphanius can also occasionally be found in the vegetated periph- ery of these lakes. Extirpation of $P$. battalgili from Lake Beyşehir proper most likely forced this species into sympatry with the $P$. anatolicus clade III found in the southern streams and marshy areas of Lake Beyşehir. Prior to anthropogenically induced sympatry, $P$. anatolicus clade III and $P$. battalgili were parapatrically distributed.

The degree of intraspecific differentiation observed among lineages of the central Anatolian Pseudophoxinus is high, and similar to that observed in the central Anatolian Aphanius. Using the molecular clock calibration of Zardoya and Doadrio (1999), the timing of diversification of major clades is largely congruent with diversification of members of central Anatolian Aphanius (Hrbek et al., 2002). The phylogenetic relationships among clades of central Anatolian Pseudophoxinus and Aphanius differ; however, this difference is non-significant (Shimodaira-Hasegawa test, $p>0.05$ ). The congruence of temporal and spatial diversification patterns of central Anatolian Pseudophoxinus and Aphanius is, therefore, most likely the product of common history driven by the same set of geological events.

\subsection{Taxonomy of Pseudophoxinus}

In spite of a recent revision of the genus Pseudophoxinus by Bogutskaya (1992), the taxonomy of the genus is still confusing. This is true of the species described as $P$. anatolicus by Hanko (1924), and especially true of $P$. fahirae, $P$. meandri, and $P$. meandricus described by Ladiges (1960). Some of these problems may, however, be alleviated if more detailed geographic information is taken into consideration. Based on combined molecular, morphological and collecting locality data, clade III is $P$. anatolicus, clade VI is $P$. fahirae, clade IV is $P$. meandri, and $P$. meandricus is most likely invalid or extinct (clade V). Our analyses also indicate that two undescribed Pseudophoxinus species occur in Anatolia; one species in the Tohma Çayı in the upper Euphrates River basin and a second undescribed species from the Develi Depression.

The oldest described species in the central Anatolian group is $P$. anatolicus; its type locality is listed as 'Eregli,' a city in the Konya plain, with a most likely origin of the types coming from Lake Ak (Akgöl). Additional material listed for this species by Bogutskaya (1992) is Lake Beyşehir. Based on this geographic data and morphology, it would appear that fishes of clade III of Pseudophoxinus are $P$. anatolicus. The sister group to $P$. anatolicus, clade I Pseudophoxinus found in the Soysali spring in the Develi Depression, represents a morphologically and genetically distinct fish from $P$. anatolicus. The Develi Depression Pseudophoxinus most likely represents a species new to science.

Pseudophoxinus fahirae also has a well-defined type locality, 'Kirkpunar, Tefenni' to which this species is 
supposedly restricted (Bogutskaya, 1992; Ladiges, 1960). Present day maps show Kirkpınar (alternate spelling of Kirkpunar) south of the city Tefenni. Based on the type locality data and morphology, fishes of the clade VI of Pseudophoxinus should, in fact, represent $P$. fahirae. Our study suggests, however, that this species is not restricted just to the type locality, but is found in the Bey Dağları region.

Pseudophoxinus meandricus and P. meandri both have type localities listed as 'Great Menderes near Isikli' in their original descriptions (Ladiges, 1960); the description of $P$. meandricus precedes that of $P$. meandri by 18 pages, thus the name $P$. meandricus would have priority if both names represented the same species. Additional non-type material listed for $P$. meandri by Bogutskaya (1992) are a number of localities in the Burdur and Salda lakes area, with one locality given as Sögüt. All localities but the Sögüt lie within the geographic area of clade IV, and therefore fishes of clade IV most likely are $P$. meandri. Sögüt lies near the geographic center of clade VI in a valley adjacent to Kırkpınar, the type locality of $P$. fahirae; fishes from Sögüt most likely are $P$. fahirae. We were unable to include fish from the Sögüt locality in this study, but it is worth noting that Bogutskaya (1992) found that the Sögüt population was meristically very different from other $P$. meandri populations which themselves showed large amount of meristic variability among populations examined.

Taxonomically the most problematic species is P. meandricus. According to Ladiges (1960) it shares its type locality with $P$. meandri. Four additional non-type lots listed by Bogutskaya (1992) are located within the geographic area of clade III. One of these localities lies just outside the city of Ereğli, the type locality of $P$. anatolicus. Based on this information and the observation that none of our specimens conformed meristically to P. meandricus as listed in Bogutskaya (1992), it is possible that $P$. meandricus is some other leuciscine fish not part of this clade, or simply may be an invalid species. If, however, geological events shaped the phylogenies of Pseudophoxinus and Aphanius (Hrbek et al., 2002) in a similar fashion, we would expect the BüyükMenderez River drainage to contain a distinct clade of Pseudophoxinus, the hypothesized clade V. Our failure to find Pseudophoxinus during six collecting seasons in this drainage could be due to bad luck. Alternately extinction of this species is a real possibility since the Büyük-Menderez drainage area has been extensively modified for agricultural purposes, and polluted by agricultural purposes.

The species discovered from the thermal source of Gögdeli Hot springs, Tohma Çayı in the upper Euphrates River basin most likely represents a species new to science. It has a disjunct distribution from all other Pseudophoxinus species known to exist in Turkey and the Middle East. It also differs in morphology and color pattern from its sister taxon Pseudophoxinus kervillei found in the Orontes River drainage system and few coastal streams between the Orontes and Seyhan/Ceyhan deltas.

The four remaining species, $P$. anatalyae, $P$. battalgili, $P$. crassus, and $P$. handlirschi appear to be taxonomically unproblematic and valid. The morphologically distinct (Bogutskaya, 1992) and critically endangered $P$. egridiri from Lake Eğirdir is not related to other Turkish Pseudophoxinus, but rather appears to be related to the Eurasian P. phoximus (Hrbek et al. unpublished data).

\subsection{Historical biogeography of central anatolia}

The clades of Pseudophoxinus have broadly overlapping distributions with the $A$. anatoliae species complex (Fig. 1; Hrbek et al., 2002) and are defined by the same geological units. Central Anatolia is composed of five main geologic units: the Kırşehir, the Menderez-Taurus, and the East Taurus blocks, the Pondites, the Sakarya continent, and the Tuzgölü and Haymana basins trapped between them (Görür et al., 1984; Sengör and Yilmaz, 1981); see Fig. 4 for schematic presentation. These areas have acted historically as separate geologic and biogeographic units. Much of the agglomeration of these geological regions began in the early-middle Eocene ( 50 MYA). However, extensive uplifting at suture zones separating various elements, and thus isolation of the elements, did not occur until the closing of the Madden complex by 12 MYA (Aktas and Robertson, 1984). The Menderez-Taurus block has undergone significant folding and uplifting 5-10 MYA due to the acceleration of northward movement of the Arabian plate and the Alanya massif (Quennell, 1984; Waldron, 1984), and thus increased isolation from other Anatolian regions, and isolation of faunal elements within the southwestern section of the block. The Tuzgölü basin has been flooded to various degrees, the last extensive flooding occurred during the Pleistocene in the Konya section of the basin (Roberts et al., 1979). It has predominantly acted as the catchment area of the Menderez-Taurus block. Although adjacent to, the Haymana basin has acted separately of the Tuzgölü basin, and has remained a catchment of the Sakarya continent throughout the geological evolution of the region (Görür et al., 1984).

Recently, Hrbek et al. (2002) hypothesized that the geological events shaping the formation of central Anatolia were likely to be the significant force driving diversification of the numerous central Anatolian organisms. The central Anatolian Pseudophoxinus species support this hypothesis. Populations are geographically restricted to geological units, and populations inhabiting the main geological units are deeply divergent from each other. This pattern of divergence in the central Anatolian Pseudophoxinus species is both spatially 


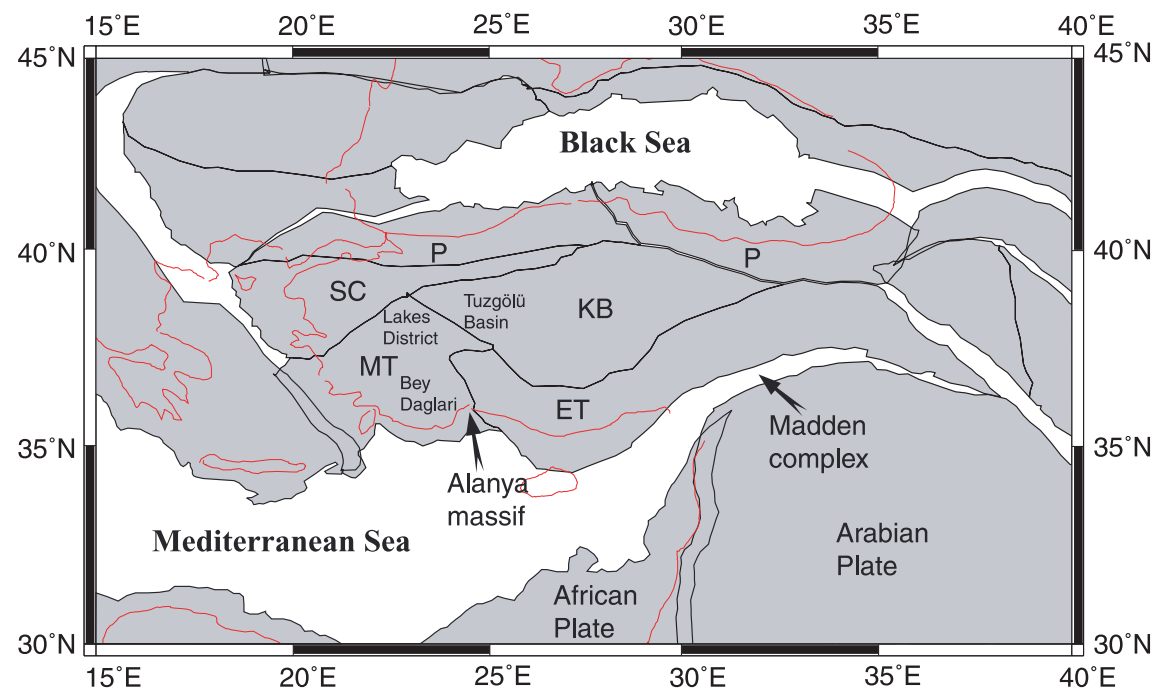

15.0 Mya Reconstruction

Fig. 4. A simplified account of the geological history of the conglomeration of Anatolia at 15 MYA based on maps of the website of the Ocean Drilling Stratigraphic Network (Hay et al., 1999). Conglomeration of all Anatolian elements occurred by 30 MYA, however, extensive uplifting at suture zones separating various elements, and thus isolation of the elements, did not occur until the closing of the Madden complex by 12 MYA. Additional uplifting of the southwestern section of the Menderez-Taurus block occurred 10-5 MYA as a result of indentation of the Alanya massif into the Menderez-Taurus block. Thin gray lines represent current coast lines. Geological blocks are shared in gray, and ancient coastlines lie between them. Codes in figures are: SC, Sakarya continent; MT, Menderez-Taurus block; KB, Kirşehir block; ET, East Taurus block; and P, The Pondites, eastern and western section, and the African and Arabian plates. (For interpretation of the references to color in this figure legend, the reader is referred to the web version of this paper.)

as well as temporally congruent with the central Anatolian Aphanius species complex.

Whether or not the pattern observed in Pseudophoxinus and Aphanius is a truly general biogeographical pattern, or a taxonomically restricted pattern only, cannot be determined with currently available data. In a recent study of central Anatolian frogs of the $R$. macrocnemis species complex, Veith et al. (2003) showed that populations inhabiting various Anatolian geological plates are of Pleistocene origin, having dispersed from a Transcaucasian refugium. The regions sampled by Veith et al. (2003) are on the same broad scale as those sampled by Hrbek et al. (2002) and the present study. Interestingly, Veith et al. (2003) discovered a second refugium in the southwestern section of the Menderez-Taurus block of Turkey, a geographic region studied also by Weisrock et al. (2001). This refugium did not act as a source of colonists for present day $R$. macrocnemis populations of central Anatolia. Populations within this refugium show little genetic differentiation from each other which is in contrast to the deep phylogenetic divergence of the $M$. luschani populations from the same region (Weisrock et al., 2001). To a lesser extent the pattern of deep phylogenetic divergence is repeated in Aphanius (Hrbek et al., 2002) and Pseudophoxinus species complexes. The southwestern section of the Menderez-Taurus block, the Dağları mountains together with the Lakes District region, experienced significant folding and uplifting 5-10 MYA as a result of the northwestern movement of the Alanya block (Waldron, 1984). It is likely that this mechanism had a profound impact on the general biogeography of the region, however, not all taxa were affected equally.

\subsection{Biological diversity in geologically complex areas}

In terms of biodiversity preservation, much of our effort focuses on tropical and Mediterranean areas that are already known to have high alpha and beta diversities. Geologically complex areas also have high biodiversity levels, but much of this diversity appears to be morphologically cryptic, and in the traditional taxonomic sense unrecognized. Although limited in scope, a number of recent molecular studies (Hrbek et al., 2002; Macey et al., 1998, 2000; Weisrock et al., 2001) including this study, suggest that geologically complex areas of the Near East contain many phylogenetically deeply divergent lineages, some showing reproductive isolation, that are otherwise morphologically difficult to differentiate. We suggest this is most likely due to fragmentation of previously contiguous areas into a parapatric series of ecologically equivalent regions. As a result of cessation of gene flow, organisms within these regions will eventually become monophyletic and reproductively isolated, but may show a large degree of morphological conservationism across ecologically equivalent regions 
potentially driven by stabilizing selection within these regions. Many of these cryptic species are likely to have limited geographic distributions and small population sizes, and thus have elevated probabilities of extinction. We must recognize and attempt to preserve this unappreciated biodiversity before it disappears.

\section{Acknowledgments}

We thank Kees Valkenburg, Bas Vlijm, Ingo Wildekamp, and Izeni Farias who were excellent and highly knowledgeable field companions. We are indebted to Walter Salzburger and Eugenio Miotti for providing outgroup samples and for discussion of results. Support for this research was provided in part by the National Science Foundation (postdoctoral Grant INT-0002213 to T.H.), the scientific research fund of Cumhuriyet University, Sivas (to F.B.), the Belgian grant for Interuniversity Poles of Attraction Program (to R.W.), and by grants from the Deutsche Forschungsgemeinschaft and the University of Konstanz (to A.M.).

\section{References}

Aktas, G., Robertson, A.H.F., 1984. The Maden complex, SE Turkey: evolution of a Neotethyan active margin. In: Dixon, J.E., Robertson, A.H.F. (Eds.), The Geological Evolution of the Eastern Mediterranean. Geological Society Special Publication No. 17. Blackwell Scientific, Oxford, pp. 375-402.

Anderson, S.A., Bankier, T., Barrell, B.G., de Bruijn, M.H.L., Coulson, A.R., Drouin, J., Eperon, I.C., Nierlich, D.P., Roe, B.A., Sanger, F., Schreier, P.H., Smith, A.J.H., Staden, R., Young, I.G., 1981. Sequence and organization of the human mitochondrial genome. Nature 290, 457-465.

Bogutskaya, N.G., 1992. A revision of species of the genus Pseudophoxinus (Leuciscinae, Cyprinidae) from Asia Minor. Mitt. Hamb. Zool. Mus. Inst. 89, 261-290.

Felsenstein, J., 1985. Confidence limits on phylogenies: an approach using the bootstrap. Evolution 39, 783-791.

Futuyma, D.J., 1998. Evolutionary Biology, 3rd ed. Sinauer Associates, Sunderland, MA.

Futuyma, D.J., Mayer, G.C., 1980. Non-allopatric speciation in animals. Syst. Zool. 29, 254-271.

Görür, N., Oktay, F.Y., Seymen, I., Sengör, A.M.C., 1984. Palaeotectonic evolution of the Tuzgölü basin complex, Central Turkey: sedimentary record of a Neo-Tethyan closure. In: Dixon, J.E., Robertson, A.H.F. (Eds.), The Geological Evolution of the Eastern Mediterranean. Geological Society Special Publication No. 17. Blackwell Scientific, Oxford, pp. 467-482.

Hall, T., 1999. BioEdit: a user-friendly biological sequence alignment editor and analysis program for Windows 95/98/NT. Nucleic Acids Symp. Ser. 41, 95-98.

Hanko, B., 1924. Fische aus Kleinasien. Ann. Hist. Natur. Mus. Nat. von Hungarn 21, 137-158.

Hasegawa, M., Kishino, H., Yano, T.A., 1985. Dating of the humanape splitting by a molecular clock of mitochondrial DNA. J. Mol Evol. 22, 160-174.

Hay, W.W., DeConto, R., Wold, C.N., Wilson, K.M., Voigt, S., Schulz, M., Wold-Rossby, A., Dullo, W.-C., Ronov, A.B., Balukhovsky, A.N., Soeding, E., 1999. Alternative global cretaceous paleogeography. In: Barrera, E., Johnson, C. (Eds.), The Evolution of Cretaceous Ocean/Climate Systems. Geological Society of America Special Paper 332, pp. 1-47.

Hrbek, T., Meyer, A., 2003. Closing of the Tethys Sea and the phylogeny of Eurasian killifishes (Cyprinodontiformes: Cyprinodontidae). J. Evol. Biol. 16, 7-26.

Hrbek, T., Küçük, F., Frickey, T., Stölting, K.N., Wildekamp, R.H., Meyer, A., 2002. Molecular phylogeny and historical biogeography of the Aphanius (Pisces, Cyprinodontiformes) species complex of central Anatolia, Turkey. Mol. Phylogenet. Evol. 25, 125137.

Huelsenbeck, J.P., Ronquist, F.R., 2001. MrBayes: Bayesian inference of phylogeny. Bioinformatics 17, 754

Ladiges, W., 1960. Süsswasserfische der Türkei. 1 Teil. Cyprinidae. Mitt. Hamb. Zool. Mus. Inst. 58, 105-150.

Macey, J.R., Schulte III, J.A., Ananjeva, N.B., Larson, A., RastegarPouyani, N., Shammakov, S.M., Papenfuss, T.J., 1998. Phylogenetic relationships among agamid lizards of the Laudakia caucasia species group: testing hypotheses of biogeographic fragmentation and an area cladogram for the Iranian Plateau. Mol. Phylogenet. Evol. 10, 118-131.

Macey, J.R., Schulte II, J.A., Kami, H.G., Ananjeva, N.B., Larson, A., Papenfuss, T.J., 2000. Testing hypotheses of vicariance in the agamid lizard Laudakia caucasia from mountain ranges on the northern Iranian Plateau. Mol. Phylogenet. Evol. 14, 479483

Mayr, E., 1942. Systematics and the Origin of Species. Columbia University Press, New York, NY.

Posada, D., Crandall, K.A., 1998. MODELTEST: Testing the model of DNA substitution. Bioinformatics 14, 817-818.

Quennell, A.M., 1984. The western Arabia rift system. In: Dixon, J.E., Robertson, A.H.F. (Eds.), The Geological Evolution of the Eastern Mediterranean. Geological Society Special Publication No. 17. Blackwell Scientific, Oxford, pp. 775-778.

Rannala, B., Yang, Z., 1996. Probability distribution of molecular evolutionary trees: a new method of phylogenetic inference. J. Mol. Evol. 43, 304-311

Roberts, N., Erol, O., de Meester, T., Uerpman, H.F., 1979. Radiocarbon chronology of the late Pleistocene Konya lake, Turkey. Nature 281, 662-664.

Rodriguez, R., Oliver, J.L., Marin, A., Medina, J.R., 1990. The general stochastic model of nucleotide substitution. J. Theor. Biol. 142, 485-501.

Sengör, A.M.C., Yilmaz, Y., 1981. Tethyan evolution of Turkey: a plate tectonic approach. Tectonophysics 75, 181-241.

Sengör, A.M.C., Altiner, D., Cin, A., Ustaomer, T., Hsü, K.J., 1988. Origin and assembly of the Tethyside orogenic collage at the expense of Gondwana Land. In: Audley-Charles, M.G., Hallam, A. (Eds.), Gondwana and the Tethys. Geological Society Special Publications No. 37. Geol. Soc. Special Pub. No. 37. Oxford University Press, New York, NY.

Shimodaira, H., Hasegawa, M., 1999. Multiple comparisons of loglikelihoods with applications to phylogenetic inference. Mol. Biol. Evol. 16, 1114-1116.

Swofford, D.L., 2001. PAUP*. Phylogenetic Analysis Using Parsimony (* and Other Methods), Beta Version 4.0b6. Sinauer Associates, Sunderland, MA.

Veith, M., Schmidtler, J.F., Kosuch, J., Baran, I., Seitz, A., 2003. Palaeoclimatic changes explain Anatolian mountain frog evolution: a test for alternating vicariance and dispersal events. Mol. Ecol. 12, $185-199$.

Villwock, W., 1964. Genetische Untersuchungen an altweltlichen Zahnkarpfen der Tribus Aphaniini (Pisces: Cyprinodontidae) nach Gesichtpunkten der neuen Systematik. J. Zool. Syst. Evol. Res. 2, 267-382.

Waldron, J.W.F., 1984. Structural history of the Antalya complex in the 'Isparta angle,' southwest Turkey. In: Dixon, J.E., Robertson, 
A.H.F. (Eds.), The Geological Evolution of the Eastern Mediterranean. Geological Society Special Publication No. 17. Blackwell Scientific, Oxford, pp. 273-286.

Weisrock, D.W., Macey, J.R., Ugurtas, I.H., Larson, A., Papenfuss, T.J., 2001. Molecular phylogenetics and historical biogeography among salamandrids of the true salamander clade: rapid branching of numerous highly divergent lineages in Mertensiella luschani associated with the rise of Anatolia. Mol. Phylogenet. Evol. 18, $434-448$.
Wildekamp, R.H., Küçük, F., Ünlüsayin, M., Neer, W.V., 1999. Species and subspecies of the genus Aphanius Nardo 1897 (Pisces: Cyprinodontiformes) in Turkey. Turk. J. Zool. 23, 23-44.

Zardoya, R., Doadrio, I., 1999. Molecular evidence on the evolutionary and biogeographical patterns of European cyprinids. J. Mol. Evol. 49, 227-237.

Zhang, D.-X., Hewitt, G.M., 1996. Nuclear integrations: challenges for mitochondrial DNA markers. Trends Ecol. Evol. 11, 247-251. 